\title{
The Amsterdam Town Hall in Words and Images
}




\title{
The Amsterdam Town Hall in Words and Images
}

\section{Constructing Wonders}

\author{
Edited by \\ Stijn Bussels, Caroline van Eck and \\ Bram Van Oostveldt
}




\section{BLOOMSBURY VISUAL ARTS \\ Bloomsbury Publishing Plc \\ 50 Bedford Square, London, WC1B 3DP, UK \\ 1385 Broadway, New York, NY 10018, USA}

BLOOMSBURY, BLOOMSBURY VISUAL ARTS and the Diana logo are trademarks of Bloomsbury Publishing Plc

First published in Great Britain 2021

Selection and editorial matter @ $\odot$ Stijn Bussels, Caroline van Eck and

Bram Van Oostveldt, 2021

Individual chapters () their authors, 2021

Stijn Bussels, Caroline van Eck and Bram Van Oostveldt have asserted their right under the Copyright, Designs and Patents Act, 1988, to be identified as Editors of this work.

For legal purposes the Acknowledgements on p. TBD constitute an extension of this copyright page.

Cover design: TBD

Cover image $\odot$ TBD

All rights reserved. No part of this publication may be reproduced or transmitted in any form or by any means, electronic or mechanical, including photocopying, recording, or any information storage or retrieval system, without prior permission in writing from the publishers.

Bloomsbury Publishing Plc does not have any control over, or responsibility for, any third-party websites referred to or in this book. All internet addresses given in this book were correct at the time of going to press. The author and publisher regret any inconvenience caused if addresses have changed or sites have ceased to exist, but can accept no responsibility for any such changes.

A catalogue record for this book is available from the British Library.

\section{Library of Congress Cataloging-in-Publication Data}

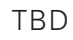

$$
\begin{array}{lll}
\text { ISBN: } & H B: & 978-1-3502-0533-8 \\
& \text { ePDF: } & 978-1-3502-0534-5 \\
& \text { eBook: } & 978-1-3502-0535-2
\end{array}
$$

Typeset by RefineCatch Limited, Bungay, Suffolk

Printed and bound in TBD

To find out more about our authors and books, visit www.bloomsbury.com and sign up for our newsletters. 